Bangl. J. Vet. Med. (2009). 7(2) : $354-357$

\title{
EFFECTS OF FEEDING PALM OIL AND SOYBEAN OIL ON BODY WEIGHT AND BLOOD CHOLESTEROL IN BLACK BENGAL GOATS
}

\author{
M. K. Islam ${ }^{1}$, M. M. R. Chowdhury ${ }^{1}$, M. M. Islam ${ }^{1}$ M. N. Hoque ${ }^{1}$ and M. M. Rahman² \\ ${ }^{1}$ Department of Physiology, Faculty of Veterinary Science, ${ }^{2}$ Department of Surgery and Obstetrics, Faculty of \\ Veterinary Science, Bangladesh Agricultural University, Mymensingh-2202, Bangladesh
}

\begin{abstract}
A study was conducted to investigate the role of dietary fatty acids (such as palm oil and soybean oil) on body weight and the level of serum cholesterol in goat in the Department of Physiology, Bangladesh Agricultural University. Three equal groups of goats were structured as control $(n=5)$, palm oil $(n=5)$ and soybean oil $(n=5)$ group and fed with normal feed, palm oil (@25g)and soybean oil (@25g) mixed feed twice a week for 2 months respectively. It was observed that the serum cholesterol of palm oil and soybean oil treated groups decreased significantly $(\mathrm{p}<0.05)$ with the advancement of experimental period. The growth performance was not significantly affected by these fatty acids. At the end of the experiment, the animals were killed and tissues from stomach and intestine were examined grossly and histologically in all groups. There were no lesions in the tissues of the animals fed on either palm oil or soybean oil.
\end{abstract}

Key words: Goat, fatty acids, palm oil, soybean oil, cholesterol

\section{INTRODUCTION}

The effectiveness of the immune system, especially in the young animals may offer immediate benefits in terms of greater ability to resist against the diseases, improved animal health and performance. Nutritional status and previous nutritional history can have a marked effect on the nature and efficacy of the immune response. Polyunsaturated fatty acids (PUFA) are known to affect many aspects of the immune system (Calder, 1998). Diet induced changes in the PUFA content of immune cells particularly the ratio of n-6 to n-3 PUFA have been shown to affect the functions of the various component of the immune response such as T-cell proliferations, antibody production by B cells, natural killer cell activity and the activity of antigen presenting cells (Calder, 1998) and also on gene expression (Fernandez et al., 1998; Hwang, 2000). Increasing the dietary supply of PUFA may be one way to enhance the magnitude and effectiveness of early immune responses to diseases. A very few work has been conducted on dietary fatty acids on immune system in goats in Bangladesh. So, a comprehensive study was necessary to establish base line information for future study. The present investigation was therefore, carried out for the overall improvement of body performances and status of serum cholesterol in goat by changing nutritional status.

\section{MATERIALS AND METHODS}

Fifteen Black Bengal goats, aged between 1.5-2 years old were randomly assigned into three equal groups $(\mathrm{n}=$ 5) and numbered as A, B and C. Group A was considered control and fed with normal feed. Group B was fed with $25 \mathrm{~g}$ palm oil and Group C was fed with $25 \mathrm{~g}$ soybean oil, mixing with normal feed twice a week for 2 months. The main ingredients of soybean oil (Teer ${ }^{\circledR}$ ) were as follows: Per serving $10 \mathrm{~g}$ (Calories-90 kcal, Cholesterol- 0.00 g, Sodium- 0.0 g, Saturates- 1.50 g, Monounsaturates- 2.00 g, Polyunsaturates- 6.50 g with Refractive Index at $40^{\circ} \mathrm{C}: 1.466-1.470$, Iodine Value: $122-135$, Acid Value: $0.06-0.12 \mathrm{mg} / \mathrm{g}$ as $\mathrm{KOH}$, Unsaponifiable matter: $3.25-4$ $\mathrm{mg} / \mathrm{g}$ as $\mathrm{KOH}$, Saponification value: $190.1-192.5 \mathrm{mg} / \mathrm{g}$ as $\mathrm{KOH}$, Volatile matter at $105^{\circ} \mathrm{C}$ Percent by mass: 0.80.12 , Wt. variation $\pm 2 \%$. Blood samples were collected after every 30 days for total serum cholesterol measurement. For collection of blood serum, blood samples were collected in sterilized test tubes and these were allowed to clot for 1 hour at room temperature. After 1 hour, the serum was taken in a set of centrifuge tube \& was centrifuged at $3000 \mathrm{rpm}$ for 15 minutes. The clear non hemolysed supernatant fresh serum was then carefully taken into a set of clean, dry, rubber stoppered, sterilized glass vials. The samples were then immediately analyzed for blood cholesterol level determination by enzymatic colorimetric test. After sacrifice of the animals, stomach and intestine were examined for gross pathological lesions. At necropsy, gross tissue changes were observed \& recorded carefully \& representative tissue samples were preserved in $10 \%$ buffered formalin for histopathological studies. 


\section{K. Islam and others}

\section{Statistical analysis}

Mean values of both the body weight and serum cholesterol in different fats and oils supplemented feed-groups were compared with the control by Duncan’s Multiple Range Test procedure.

\section{RESULTS AND DISCUSSION}

\section{Effects of fatty acids (soybean oil and palm oil) on serum cholesterol level of goat}

The effects of fatty acids (soybean oil and palm oil) on blood cholesterol level of goats are presented in the Table 1. Table 1 exhibits that at the pretreatment stage the serum cholesterol level of different groups of animals was different. With the advancement of age the serum cholesterol of control groups was increased. The highest serum cholesterol level $(105.20 \mathrm{mg} / \mathrm{dl})$ was found at the $60^{\text {th }}$ day of the experiment, which was statistically significant $\left(\mathrm{p}^{<0.05}\right)$ as compared to $30^{\text {th }}$ day and $1^{\text {st }}$ day of the experiment. On the other hand with the time the serum cholesterol of the palm oil treated animals decreased. The highest serum cholesterol level (111.3 mg/dl) was found on $1^{\text {st }}$ day of the experiment. On the $60^{\text {th }}$ day of the experiment the serum cholesterol level of palm oil treated animals was $90.76 \mathrm{mg} / \mathrm{dl}$ which was the lowest and was statistically significant $(\mathrm{p}<0.05)$ as compared to $30^{\text {th }}$ day of the experiment. The decrease in serum cholesterol level of palm oil treated animals was consistent with the authors (Chowdhury et al. 1995; Fernandez et al., 1996; Park et al., 2001; Choi et al., 2004; Edionwe and Kies., 1998). This was due to the effect of some potent cholesterol lowering agents existing in palm oil. With the advance of age the serum cholesterol of soybean oil treated animals was also decreased. The highest serum cholesterol $(109.80 \mathrm{mg} / \mathrm{dl})$ was found at first day of the experiment. At the $30^{\text {th }}$ day of the experiment the serum cholesterol level was $106.80 \mathrm{mg} / \mathrm{dl}$ which was statistically insignificant as compared to first day of the experiment. At the last day of the experiment the serum cholesterol level of soybean oil treated animals was 95.13 $\mathrm{mg} / \mathrm{dl}$ which was statistically significant $(\mathrm{p}<0.05)$ as compared to $30^{\text {th }}$ day of the experiment. This result was consistent with a report suggested by Anderson et al. (1995). The decrease of serum cholesterol was due to soy phytoestrogens (iso flavones, genistein and daidzein) absorbed onto the soyprotein were suggested as the agent reducing serum cholesterol.

Table 1. Effects of fatty acids feeding on body weight and cholesterol level in Black Bengal goats

\begin{tabular}{|l|l|l|l|l|l|l|}
\hline \multirow{2}{*}{$\begin{array}{l}\text { Group of } \\
\text { animals }\end{array}$} & \multirow{2}{*}{ Parameters } & \multicolumn{2}{|l|}{ Days of experiment } \\
\cline { 3 - 7 } & & $1^{\text {st }}$ day & $15^{\text {th }}$ day & $30^{\text {th }}$ day & $45^{\text {th }}$ day & $60^{\text {th }}$ day \\
\hline \multirow{2}{*}{ Control } & Body weight(kg) & $19.00^{\mathrm{a}} \pm 2.65$ & $19.12^{\mathrm{a}} \pm 2.67$ & $19.27^{\mathrm{a}} \pm 2.67$ & $19.67^{\mathrm{a}} \pm 2.74$ & $20.10^{\mathrm{a}} \pm 2.80$ \\
\cline { 2 - 7 } & Cholesterol$(\mathrm{mg} / \mathrm{dl})$ & $100.90^{\mathrm{a}} \pm 0.64$ & & $104.20^{\mathrm{a}} \pm 1.65$ & & $105.20^{\mathrm{b}} \pm 1.00$ \\
\hline \multirow{2}{*}{ Palm oil } & Body weight(kg) & $11.33^{\mathrm{b}} \pm 3.06$ & $11.53^{\mathrm{b}} \pm 3.15$ & $11.87^{\mathrm{b}} \pm 3.20$ & $12.27^{\mathrm{b}} \pm 3.23$ & $12.63^{\mathrm{b}} \pm 3.25$ \\
\cline { 2 - 7 } & Cholesterol(mg/dl) & $111.30^{\mathrm{a}} \pm 2.51$ & & $108.30^{\mathrm{a}} \pm 3.89$ & & $90.76^{\mathrm{b}} \pm 2.24$ \\
\hline \multirow{2}{*}{$\begin{array}{l}\text { Soybean } \\
\text { oil }\end{array}$} & Body weight(kg) & $18.33^{\mathrm{a}} \pm 1.53$ & $18.67^{\mathrm{a}} \pm 1.48$ & $19.07^{\mathrm{a}} \pm 1.48$ & $19.70^{\mathrm{a}} \pm 1.51$ & $20.23^{\mathrm{a}} \pm 1.50$ \\
\cline { 2 - 7 } & Cholesterol$(\mathrm{mg} / \mathrm{dl})$ & $109.80^{\mathrm{a}} \pm 1.10$ & & $104.83^{\mathrm{b}} \pm 3.85$ & & $95.13^{\mathrm{b}} \pm 7.13$ \\
\hline
\end{tabular}

The values followed by similar superscripts in the same column are not statistically different at $\mathrm{p}<0.05$ by Duncan’s Multiple Range Test procedure.

\section{The effects of fatty acids (soybean oil and palm oil) on body weight of goat}

The effects of fatty acids (palm oil and soybean oil) on body weight are presented in the Table 1 . With the advancement of age, the body weight of treated animals was not increased significantly. This result is primarily similar to the works of previous researchers (Choi et al., 2004; Islam et al,. 2002), who observed that feeding with hydrogenated soybean oil (SHSO) containing about 21\% conjugated linoleic acid did not significantly affect growth performance of rats Valerie et al. (2002) reported that a diet high in saturated fat compared with one high in unsaturated fat was reported to either increase or decrease or have no effect on body weight.

\section{Gross and histological observation of tissues}

At the end of the experiment, the animals were killed and abomasum, duodenum were examined for any gross or histological changes. But no lesion was observed in the tissues collected for gross and histological study. 


\section{Effect of fatty acids on health of Black Bengal goats}

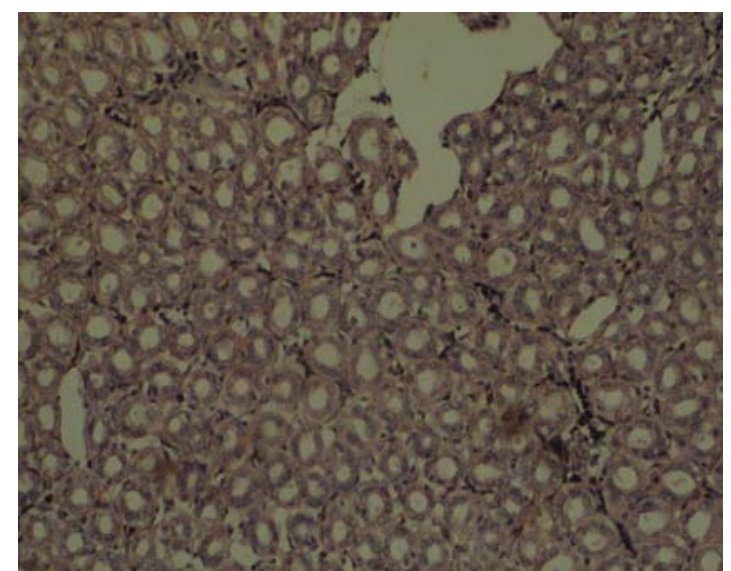

Fig. 1a

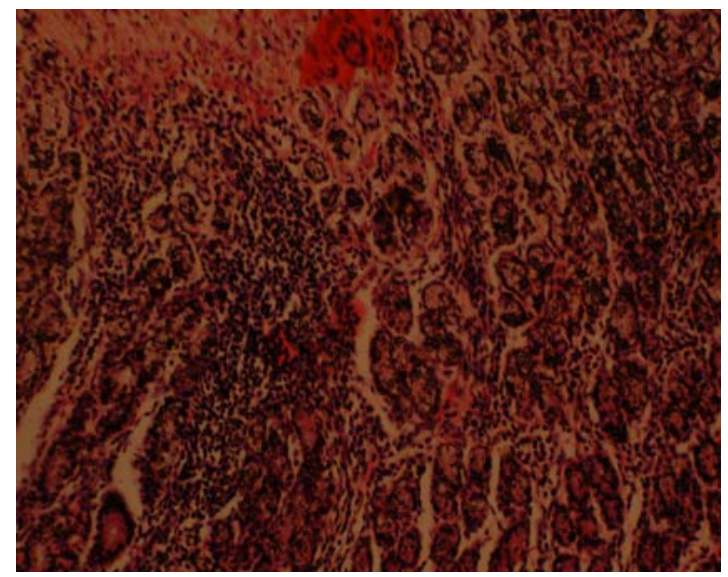

Fig. 1c

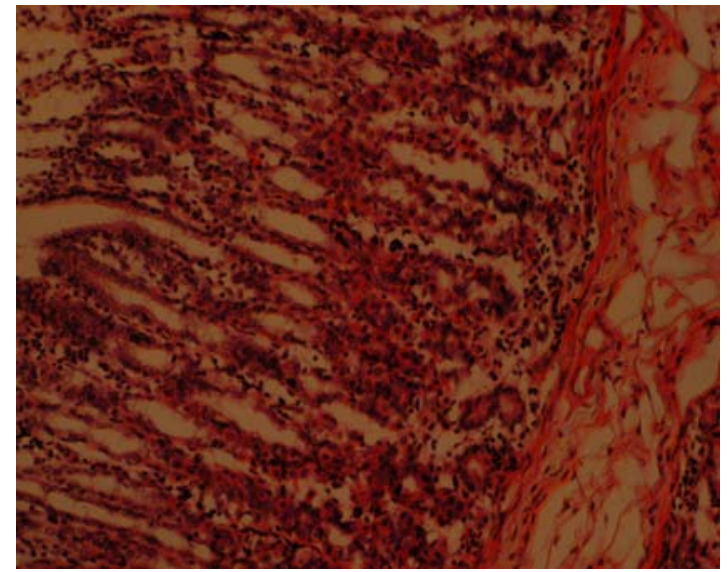

Fig. 2b

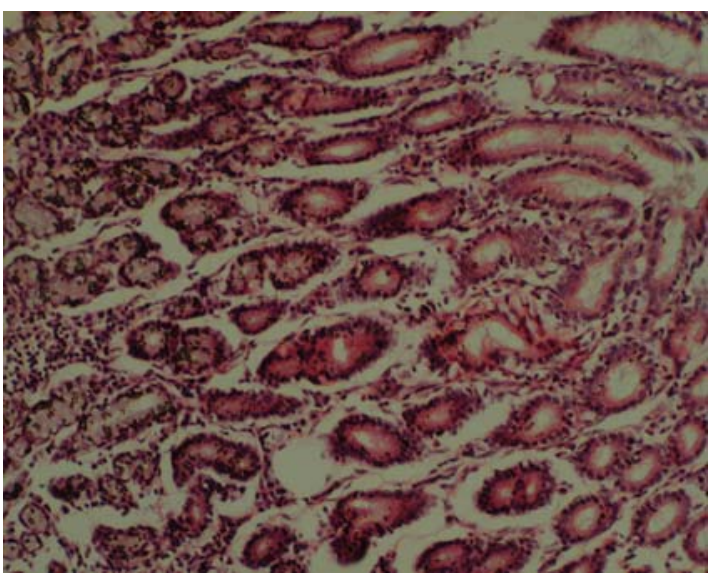

Fig. 1b

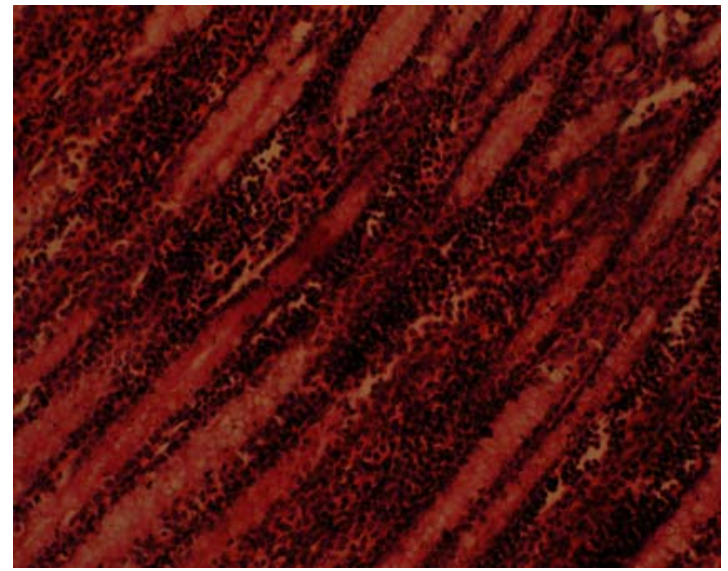

Fig. 2a

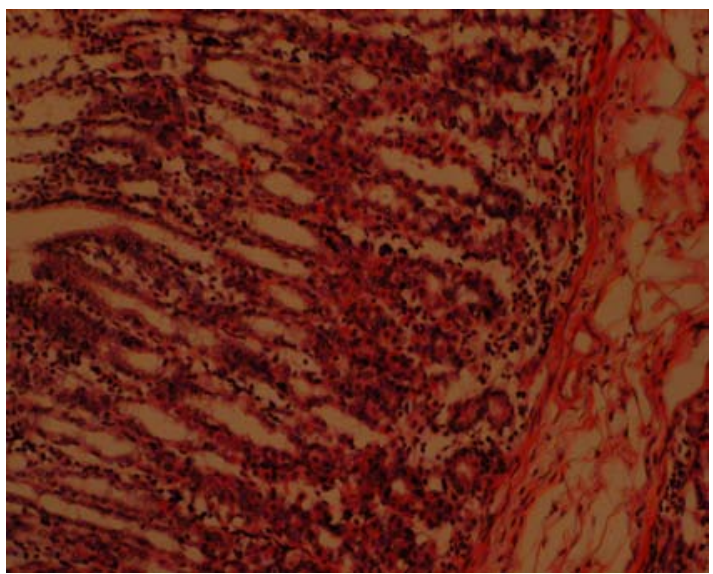

Fig. 2c

Fig. 1. Histopathological section of abomasum of goat (H\&E x 85) showing, a) infiltration of leukocyte in control group; b) no lesion was found in soybean oil treated animals; c) no lesion was found in palm oil treated animals.

Fig. 2. Histopathological section of duodenum of goat (H\&E x 85) showing, a) no lesion was found in control animals; b) no lesion was found in soybean oil treated animals; c) no lesion was found in palm oil treated animals. 


\section{K. Islam and others}

The experiment reveals that palm oil and soybean oil have a cholesterol lowering effect. The body weight is almost unaffected by dietary treatment of these fatty acids. No lesion has been identified in the gastrointestinal mucosa of the parasitized animals fed on fatty acid mixed diet. Further study is proposed to the detailed investigation on the distribution of special immune cells such as globule leukocytes and mast cells in the gastrointestinal tract through immunohistochemistry upon fatty acid supplementation.

\section{ACKNOWLEDGEMENTS}

The authors are grateful to University Grant Commission of Bangladesh for their financial assistance to conduct the experiment.

\section{REFERENCES}

1. Anderson JW, Johnstone BM and Cook-Newell ME (1995) Meta-Analysis of the Effects of Soy Protein Intake on Serum Lipids 333:276-282.

2. Calder PC (1998). Dietary fatty acids and lymphocyte functions. Proceeding of Nutrition Society 57: 487-502.

3. Choi N, Kwon D, Yun S, Jung M and Shin H (2004). Selectively hydrogenated soybean oil with conjugated linoleic acid modifies body composition and plasma lipids in rats. Journal of Nutritional Biochemistry 15: 411-417.

4. Choudhury N, Tan L and Truswell AS (1995). Comparison of palm oil and olive oil effects on plasma lipids and Vit E in young adults. American Journal of Clinical Nutrition 61: 1043-1061.

5. Edionwe AO and Kies C (1998). Comparison of palm, palm stearin, palm olein and partially hydrogenated soybean oils: Effects of serum lipids and fecal fatty acid excretions of adult humans. International Journal of Food Science and Nutrition 49: 447-483.

6. Fernadez S, Gonzlez C, Diez F, Fneyo AM, Gutierrez JM and Patterson AM (1996). Long term effects in two generations of enriches soybean oil and olive oil diets on some cardiovascular and biochemical parameters in male rats. International Journal of Vitamin and Nutrition Research 66: 343-399.

7. Fernandez G, Troyer DA and Jolly CA (1998). The effects of dietary lipids on gene expression and apoptosis. Proceeding of Nutrition Society 57: 543-550.

8. Hwang D (2000). Fatty acids and immune responses- A new perspective in searching for clues to mechanism. Annals of Review in Nutrition 20: 431-456.

9. Islam K, Ahmed N, Majumder S, Islam R and Barek MA (2002). Effect of dietary supplementation of soybean oil on body weight and certain hematobiochemical parameters in broiler birds. Bangladesh Veterinary Journal 36: 15-17.

10. Park SW, See SH, Namkung H, Paik IK and Shin IS (2001). Effects of soybean oil supplementation on the performance of weaning pigs. Journal of Animal Science and Technology 43: 477-484.

11. Valerie R, Suzanne R, Gilles F and Patrick C (2002). Body weight, body composition and energy metabolism in lean and obese zucker rats fed soybean oil or butter. American Journal of Clinical Nutrition 75: 21-30. 